\title{
The Conflict in Indonesia's Forestry Sector: A Case Study of a Community Conflict with Company Industrial Plantation Forest (HTI) in Pelalawan Riau Province
}

\author{
Panca Setyo Prihatin ${ }^{1}$, Agung Wicaksono ${ }^{1}$ \\ \{panca.ip@soc.uir.ac.id $\left.{ }^{1}\right\}$
}

\begin{abstract}
This article describes the forestry sector conflicts that occur in Pelalawan District, Riau Province. The forestry conflict occurred between local communities and industrial timber plantations. The author finds several factors that are the root of the conflict, namely historical-sociological factors, economic inequality factors, collisions between customary forests and state forests, and policy inconsistencies. These factors are factors that cause a prolonged conflict between the community and the company. The long-standing conflict has not been resolved because the central and regional governments (Provincial and District) are not serious in resolving existing conflicts. Therefore, the author feels that there needs to be a model for resolving forestry conflicts in the future. The author assumes that there must be one main actor who is in charge of conflict resolution. The most appropriate actor is the Governor of Riau (Provincial Government). The governor is deemed more appropriate in formulating various matters relating to the resolution of conflicts in the forestry sector.
\end{abstract}

Keywords; Conflict, Forestry Sector, Pelalawan

\section{Introduction}

The new order era is an era where the forestry sector policy is given a clear legal basis. To support the increase of foreign investment and domestic capital in the field of exploitation of forest resources, the government built a legal instrument that began with the establishment of Law No. 5 of 1967 concerning Basic Forestry Provisions. Then, to implement the provisions concerning forest exploitation which underlie the policy of granting forest resource exploitation concessions, PP No. 21 of 1970 juncto PP No. 18 of 1975 concerning Forest Concession Rights and Forest Product Collection Rights (HPH and HPHH). As soon as this Government Regulation was issued, large-scale exploitation of forest resources was carried out by the government, especially in Sumatra, Kalimantan, Sulawesi, Maluku and Irian Jaya (Papua), through the granting of HPH and HPHH concessions to foreign and capital owners. domestically in the form of Private-Owned Enterprises (BUMS) and State-Owned Enterprises (BUMN).

In Pelalawan District, the result of the forest management policy has caused conflict which continues to this day. Land-use conflicts between communities and companies holding Industrial Plantation Forest Concession Rights (HPHTI) in Riau generally and in Pelalawan District especially began with the issuance of the Minister of Forestry's Decree on Forest Management Agreements (TGHK) in 1986 in Riau Province, which was determined as a 
permanent production forest area. based on the Final Report of the Study of Natural Resource Potential in Pelalawan District (2009; 70)

in 2008, the area of Industrial Plantation Forest was 429,070.97 hectares. However, in the HPHTI area there are villages / villages, community plantations areas as livelihood forests that have been settled, managed, used as sources of life long before the Minister of Forestry's Decree on the provision of HPHTI to 2 (two) large companies incorporated in Sinar Mas Group and APRIL Group.

Conflict in land use arises because of differences in perceptions between several parties in land use. Differences in perception is referred to in this conflict is manifested in the form of basic act of each party in conducting land use. The impact of the land use conflict that has not been resolved to date is the incomplete preparation of the Riau Provincial Spatial Plan (RTRWP). This is due to the lack of common ground in resolving land status. Conflicts that occur in land use have many dimensions, both legal, social and political. So as to resolve the conflict needs to be approached on these aspects so that the resolution of conflicts to the root causes of the conflict.

This article describes the factors that caused the horizontal conflict in the forestry sector in Pelalawan District. Factors that cause conflict are important to know to be able to see the true root of the problem. Then, the author made a model for resolving forestry conflicts in the future. With this model, it is expected that it can help resolve the existing problems so that the conflict can be resolved immediately

\section{A. Conflict}

Conflict in Ritzer and Goodman [1] is basically something that is unavoidable in our lives. Conflict is part of social interaction that is dissociative. This conflict if allowed to drag on and on and not be handled immediately will lead to social disintegration of a nation. A situation that has a great opportunity for conflict to arise is a difference. The difference that is meant is the difference in interests.

Weber argues that the relationships that arise are efforts to gain a high position in society. Weber emphasized the importance of power in every type of social relationship. Power is a social dynamics generator in which individuals and groups are mobilized or mobilized. At the same time power (power) is the source of conflict, and in most cases there is a combination of interests from each social structure that creates the dynamics of conflict. Emilie Durkheim in one of his theories the social movement mentions collective consciousness that binds individuals through various symbols and social norms. This collective awareness is a fundamental element of the existence of the group. Members of this group can create altruistic suicides to defend the existence of their group [2]. Although not implicitly discussing conflict theory, Weber's theory basically tries to analyze social movements and conflicts. Social movements for Weber can lead to conflicts like what happened during the French Revolution.

Conflicts between a group and other groups can cause group member solidarity and integration to increase, and try to keep members from breaking up. However, this is not the case if a group no longer feels threatened by another group, group solidarity will be relaxed, and symptoms of possible differences in the group will appear. On the other hand, if a group is always threatened by other groups, it can lead to growing and increasing solidarity of group members.

In the case of the forestry sector conflict in Pelalawan District, two conflicting parties are communities around Industrial Plantation Forests (HTI) and Industrial Plantation Forest Companies (HTI). These two parties are parties who maintain their arguments for each other relating to the land in dispute. The community believes that this is their land which has been 
controlled for generations. While companies assume that they are legal landowners because they have official permission from the government. The government as a party that must be present in their midst tends to be ignorant of the conflict. This is a real portrait of the forestry sector conflict in Pelalawan District.

\section{B. Conflict Resolution}

Conflict resolution is a process of analysis and problem solving that takes into account individual and group needs such as identity and recognition of institutional changes needed to meet needs. In every conflict, a solution is always sought. Conflicts can sometimes be resolved by both parties to the conflict directly. But not infrequently also must involve a third party to mediate and find a way out either by the state or as a Regional Organization and even International Organizations

Theorists supporting conflict resolution (conflict resolution) generally argue that in communal and identity conflicts, the parties to the conflict are very difficult to compromise on the needs they consider to be very fundamental. However, this theoretical group believes in the possibility of conflict change if the parties to the conflict are helped to explore, analyze, and question again and then re-frame their positions and interests over the conflict being experienced.

Therefore, the theory of supporting conflict resolution (conflict resolution) emphasizes the importance of interference from other parties that have the potential to cooperate with conflicting parties in order to strengthen thoughts within the framework of new relations between conflicting parties. In essence, conflict resolution (conflict resolution) looks back at the root causes of conflict and identifies creative solutions that are likely by parties involved in the conflict to be missed from the settlement commitments that have been made [3].

Conflict Resolution is a process that must exist to resolve the conflict in the forestry sector in Pelalawan District. Third parties are actors who should be there to resolve existing conflicts. Third parties actually already exist, namely the government. But the government tends to neglect. The Central Government, Provincial Government and Regency Government seem to close their eyes so that this conflict becomes prolonged and not finished. Therefore, this article contains a model for future conflict resolution so that the conflict can be completed soon.

\section{Method}

Research in this study uses qualitative research methods. According to Denzin and Lincoln in Creswell. Qualitative research consists of a series of material interpretive practices that make the world visible. These practices transform the world. They transform the world into a series of representations, including field notes, interviews, conversations, photos, recordings, and self-memos [4]. One type of qualitative research is case studies. According to Creswell case study research includes the study of issues in one or several cases in a limited system (setting and specific context). Further according to Creswell [4], the type of qualitative case study is distinguished based on the size of the limitation of the case for example, whether the case involves one individual, several individuals, a group, a large program or an activity. Case studies can also be distinguished in terms of the objectives of the case analysis.

This article is the result of the author's research using the case study method. Case studies are considered appropriate to examine the conflict in the forestry sector in Pelalawan District. This research is a research that focuses on one object, namely the forestry sector conflict. This 
also relates to various actors related to society, companies and government. This makes this research very appropriate using qualitative research with a type of case study.

\section{Result and discussions}

Factor that Cause Prolonged Conflict: Historical and Sociological Factors, Economic Gap Factors, Clash Indigenous Forest and State Forest, and Policy Inconsistencies

The If you look at history, forest management in Indonesia has existed since the Old Order era. During the old order, forest management and management was only planned and implemented in Java, known as teak forest management. While outside Java, it has not been as advanced as in Java, one of the obstacles is that the demand for jungle wood is not high and the infrastructure has not been adequate [5].

Law Number 5 Year 1967 concerning Basic Forestry Provisions (Undang-undang Pokokpokok Kehutanan/UUPK) came into effect when the new order began to take power. In fact, the General Explanation of Law Number 5 Year 1967 states that, this UUPK is a step towards towards the unification of national law in the forestry sector, and is the parent of laws and regulations governing various fields in forestry activities.

To implement the UUPK, a series of regulations have been issued. If examined in the provisions of the UUPK and its implementing regulations, it is understandable that the existence of the law and its implementing regulations prioritize economic interests rather than environmental conservation efforts.

This is as stated in the General Explanation, namely; The Indonesian nation is a nation blessed with a Almighty God who is a homeland that is rich with natural resources, among other things with a very large forest. The intensive extraction of natural resources in the form of forests is the implementation of the mandate of the people's suffering which should not be postponed any longer in the context of national economic development to realize people's welfare [6]. Development capital needs are a top priority at the time. Tropical forest exploitation has in some cases succeeded in supporting national development in terms of foreign exchange earnings, employment, growing regional development and the development of forest products industries. Natural resources (forests, mines, water, minerals) are viewed in the context of economic sense and are not yet understood as ecological and sustainable sense.

Entering the reform era in 1998, there was a structuring of the life of the nation and state by carrying out constitutional reform, legislative reform, and bureaucratic reform. As a result of legislative reform, many laws and regulations on the products of the New Order were replaced and adjusted to the spirit of reform. One of them was revoked Law Number 5 of 1967 concerning the Basic Provisions of Forestry, which was replaced by the enactment of Law Number 41 of 1999 concerning Forestry (UUPK). Since the Era of Reform, development and forest management face new challenges. There is a dilemma in forestry policy. On the one hand, the Central Government is considered to dominate decision-making in forest management. However, on the other hand when districts and their communities were given wider opportunities to manage forests in their area, in some areas there was an explosion in the granting of small-scale concession permits which resulted in increased rates of forest destruction. This was evident, during 1997-2000, at the beginning of the era of regional autonomy, the rate of forest destruction increased from 1.87 million hectares to 2.83 million hectares due to euphoria of reforms that led to massive deforestation. However, from 2002 to 2005 the rate of forest degradation has begun to decline to 1.18 million hectares per year. 
The cause of the emergence of conflict can actually be easily tracked, namely seeing it from the historical and sociological aspects. This aspect can tell about the root of the conflict which later became "exploded later on. In general, there are two frictions that occur in cases of conflict in the public domain. This happens between local (local) communities and migrant communities.

Local communities are a group of people who have long lived in an area and are usually homogeneous in character. Customs and single tribes make rare disagreements or even friction between fellow members of the community. The local community is a unity that is difficult to be separated from its attachment to the forest. Forests for them are a significant source of livelihood. This habit has long been passed down by their ancestors to manage various forest products to make a living

Over time, the presence of companies holding HPHTI permits began to disturb their lives. The policy of the New Order era did make the forest as a source of state income. Forests can provide a large amount of foreign exchange for Indonesia, especially at that time the development agenda was being enforced by the government. The presence of the company certainly brings a large amount of workforce. But almost the majority, the workforce comes from outside, not from the local community. So that the presence of outside workforce raises a new category of society which is commonly referred to as newcomers. Not infrequently also, the migrant community then lived permanently and had a family and gave birth to offspring. The number from year to year has increased, making the comer community even stronger.

As an entity that relies on forest resources to fulfill its life's needs, the local community certainly feels disturbed by the presence of HPHTI companies that not only plunder their forests, but also bring new communities, namely migrants. Local people who have rarely interacted with newcomers have become resistant to the presence of new people, which is certainly a new culture. In Pelalawan district itself, the major The existence of the forest in their village suddenly began to be threatened. The behavior of the majority of the community was gardening, farming, looking for quality wood, looking for sialang honey, fishermen in rivers and so on. As said by Atan Bandit (a local citizen):

We used to be happy. Our forests are managed by not destroying them and taking what is necessary. If the company only plays brushes. We used to be able to easily enter and enter the forest. Our forests are vast, we have lots of honey, we also eat lots of fish. We used to look after the forest. Now the company is destroying our forests. We are sad [7].

Along with their reduced mobility due to the extent of permits given by the government to HPHTI companies. Limited space of movement, reduced income and an increase of people in the local community cause tremendous unrest. Local people began to feel stuck and could not do much other than having to accept increasingly difficult conditions. This condition accumulates continuously so that at some point it explodes and causes conflict.ity of migrants come from Java.

On the one hand, migrants in general have become economically well-established because their income as HPHTI company workers is promising in terms of income. Coupled with certain skills that make them able to "be creative" in increasing the coffers of their income. This unequal economic condition causes social jealousy. Local people feel colonized in their own area. The presence of the company does not provide anything meaningful other than just making it more difficult for them. As Rustam Bindu (Local Residents) said:

The company is carrying workers from outside. Most of Java. We are here confused about making money. Our forest has been taken, we are not given work. It's our life. 
Those migrants can be richer than us native people here. We feel jealous because they are prosperous, while we are getting worse [8].

These conditions are things that are at the root of the problems that build conflict. Conditions in the community that were formerly peaceful and peaceful, especially from an economic perspective, began to be disrupted by the presence of HPHTI companies which were followed by economic progress gained by migrants. Occupation in their own area is a psychological expression embedded in the minds of local people.

Then, which is one of the factors causing forestry conflict is economic disparity (gap). Forestry conflicts that occur have something to do with the interpretation of local communities about the presence of companies operating around them. The community interpreted that the presence of the company around them only damaged what they had maintained for a long time. This destructive perception was built by the community from time to time due to the lack of communication that was built with them either from companies that were given permission or the government as the one who gave permission.

We are tired of taking care of the forest. They come to spend immediately. we are disappointed to see it. We (the people) don't want to destroy the forest. They (companies) just change into HTI. We become stressed. Our economy is getting worse due to the decreasing forest area we have [9].

The main focus is more on the government as the party that gives permission to the company. The government in granting permits tends to be negligent in conducting socialization to local communities. Local people are not directly involved by the government, even though the permit has a broad impact on their lives later. Then, the community is not absorbed to be submitted to the company to take part in the company. Local people only become spectators on their own land. Many companies enter by taking part in bringing in labor from outside. Of course this is very unfair from the local community's own regulations. So it is not wrong if they interpret that companies will only damage their forests and not have a positive impact on their lives in the future.

We try to keep asking HTI companies to be sensitive to the condition of the community around HTI. Don't just make the most profit but also pay attention to them. We always try to remind the company. Only they often ignored our appeal. Meanwhile, we also difficult because of the authority of the high officials up there to put pressure on the company HTI [10].

The government here tends to rest on the logic of reaping foreign exchange as much as possible from the forest sector. The forestry sector is indeed a strategic sector that the government relies on to carry out massive development, especially in the New Order era. The government is not sensitive to the conditions that will cause conflict in the future. Local communities are not given a proper position which leads to a poor public interpretation of the company and government.

Conflict is also caused by the collision of the status of indigenous forests and state forests. Customary forests are forests that are in the area of customary law communities. Customary forests based on Law No. 41 of 1999 is a state forest whose management is handed over to indigenous peoples. However, based on the Constitutional Court Decision No. 35 / PUU-X / 2012 says that customary forests are not state forests whose management is left to indigenous peoples but forests that are wholly owned by indigenous peoples. State phrases are omitted there so that indigenous peoples are now positioned to be stronger in position, especially from the forest land tenure sector.

In addition to customary forests, there are also forests that have status as production forests. If customary forests are under the authority of customary law communities, production 
forests are forests whose authority is in the hands of the government or private parties that have been given permission by the government to produce various forest products. This production forest is the target for meeting the needs in the fields of development, industry and export. The true production forest is to meet various human needs that are closely related to forestry resources. Production forests fall into the category of state forests.

In relation to the conflicts that occur, the status of customary forests and production forests are two entities that often collide. Many HPHTI companies (production forests) whose land often overlaps with customary forest areas. This is what causes local (adat) communities to become increasingly inflamed because they feel their land is being annexed by the company. But companies usually rely on area permits granted by the government. Often there are slices between customary forests and production forests in the field. This resulted in considerable horizontal conflict because the forest was related to the economic needs of both parties.

Many occur, customary forest areas are located in areas that are besieged or confined by company land. In forestry, the event is called an enclave. In relation to the enclave, the community and companies can exchange forest areas which can actually ease disputes easily. Exchange can be done by taking into account the various laws and regulations. In essence, customary forests are a source of community livelihood that must be preserved, in addition to the state revenues that are obtained from operating companies.

Last, the researchers noticed that their policy inconsistencies that make forestry a prolonged conflict. In terms of regulations, there are many related to forestry in Indonesia laws. But specifically, Law No. 41 of 1999 is a law that specifically and specifically regulates the forestry sector in Indonesia. UU no. 41 of 1999 is a special legal umbrella commonly referred to as lex specialist in forestry affairs. So when talking about the forestry sector, the law must be the main reference that must be referred to first.

The forestry sector is a sector that is very vulnerable to conflict. Especially if it relates to literacy. Generally, the community around the forest is always in conflict with companies that have been granted forest concession rights (HPH) by the government. People who feel that they do not accept the arrival of a company which is in fact conflict with the private sector. Conflicts that occur from small scale to large scale, often even cause fatalities on both sides. Conflict is a necessity when talking about forest resource management.

The government is in accordance with its role as a mediator. But of course the reality is not that easy. In the government itself so far there are 3 main levels, namely the central government, provincial government and district governments. The three actors clearly are legitimized by the people. They are obliged to resolve precisely and quickly the conflicts that exist between the private sector and society so as not to expand and make the situation worse.

The slow resolution of the conflict in the forestry sector is the mouth of the government's lack of readiness and unpreparedness. Throwing responsibilities between levels of government is often encountered in various cases of forestry conflicts in Indonesia. The conflict between levels of government is the majority between the provincial government and the central government. District / city governments are rarely involved because indeed the authority in the forestry sector has now been drastically reduced by the Local Government Law. The Provincial Government considers that the resolution of the forestry sector conflict is the authority of the central government which in this case is the Ministry of Environment and Forestry. The basis of the argument of the provincial government is the matter in the law, the central government is an institution that almost fully has strategic authority in the forestry sector. While the provincial government is more to "trivial" matters in the forestry sector. This argument is the basis for the devolution of the resolution of forestry conflicts to the Ministry of Environment and Forestry 
Relatively there is a fairly basic misunderstanding for the provincial government in resolving forestry conflicts. In the Regional Government Law, in the article it is explained that forestry affairs are more to the central government. It should be underlined that social conflicts that exist in the region are a matter of general government. General government affairs clearly exist in the president as head of government. But in its implementation, it can be delegated to the local government in this case the governor as a representative of the central government in the region or even the regent and mayor. Then in its settlement must involve vertical agency in the area in accordance with the main function of the problem. If it is related to social conflicts in the forestry sector, of course, coordinate and synergize with the Ministry of Forestry's representative bodies or offices in the regions. This is because in Law Number 23 Year 2014 it is clear that handling conflicts is included in the general government section which is by law the authority of the president.

To resolve the forest conflict, this should be the domain of the provincial and central government. We in the district have the authority in the forest sector to be exempt. So regarding the problem of forest conflict, we cannot intervene too much. Only provinces and centers have authority [10].

The confusion of interpretations of forestry makes the conflict not resolved. The conflict will continue to occur and even increase when there is no direct intervention from the state because its agent, the government itself still does not fully understand its task in reducing conflict. This interpretation should be straightened out if you want the conflict to be finished. Moreover, conflict in the forestry sector is a matter of extraordinary energy, both from a material and psychological perspective.

\section{Future Forestry Sector Conflict Resolution Model}

The section offers a model for resolving forest conflicts, especially conflicts that occur in Pelalawan District. The author considers this model suitable to be applied in resolving forestry conflicts. This model can be taken into consideration for policymakers to resolve forestry conflicts not only in Kab. Pelalawan, but in many other parts of Indonesia. The author makes a model for solving forestry conflicts with the chart below. The chart below explains clearly how forestry conflicts, especially in Pelalawan District, can be completed soon.

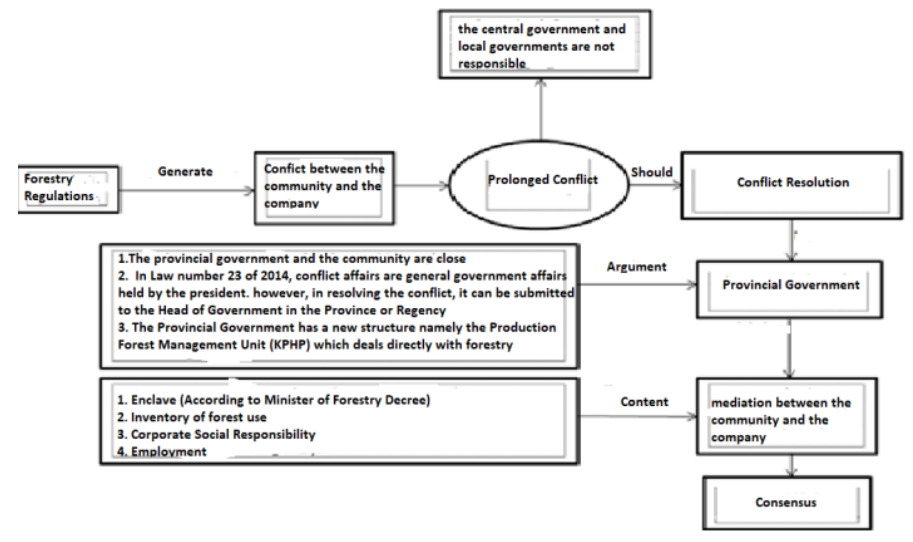

Cases of conflict between communities and HTI companies are conflicts that have long existed and have not been completed. Regarding land disputes, social jealousy, and economic 
inequality are among the main contributors to why conflicts continue to occur. Forestry conflict is indeed one of the conflicts that is often encountered, especially in Sumatra and Kalimantan, which have large forest resources and the people depend on the forest for their livelihoods.

In Pelalawan District, the conflict was prolonged because of the absence of the main actors who could ease or find a way out of the conflict. The Regional Government in this case the Pelalawan District Government feels that it is not its responsibility, but the central government as an institution that is fully responsible in the forestry sector. Moreover, new rules regarding the authority of the district government are cut out for those related to forestry. Practically with this, the Pelalawan District government cannot do much because they are no longer the main actors to solve problems related to forestry.

The provincial government as an entity that has a large portion in the forestry sector also seems to be slow and does not do much to resolve the forestry conflict. The position of the provincial government is indeed stronger than that of the district government, but still the provincial government of Riau considers that it is not its responsibility. This is because the permit from forestry parties is not their responsibility, but the responsibility of the central government and district government.

The central government also cannot be optimal in resolving conflicts. The long range of government factors is one of the factors that causes the center to not interfere too much to help resolve existing conflicts. Then the central government also has the main argument which is quite rational formally, namely that conflict affairs are the duty of the general government whose implementation can be handed over to the regional head. LHK Ministry as a ministry in charge of forestry affairs. What should be underlined is that the conflict is not about forestry. Social conflict is something that is the main focus of completion. Regarding that in the forestry sector, it is two different things. So the LHK Ministry is also not too focused on efforts to resolve the forestry sector conflict in Pelalawan District, Riau Province.

Regarding the resolution of forestry sector conflicts that occur in Pelalawan district, there must be a main actor who functions as a mediator. The main actor is a necessity given that there must be a main actor who is responsible for resolving the conflict so that it does not drag on as it is now. Based on what researchers have understood, that the Regional Government is the main actor who must intervene to resolve this conflict.

The local government referred to here is more to the position of the Riau provincial government. Riau Provincial Government is the main organ that can be relied upon to solve problems. Riau Provincial Government is considered to have the right position legally formal. First, Riau Provincial Government has two faces. On one hand, the Riau Provincial Government is a representative of the region, but also the representative of the center. This position can make Riau Provincial Government easier to work in resolving conflicts. Downward and upward coordination can be easier. Second, for cases of conflict in the forestry sector, the Riau Provincial Government is considered to have more authority than the district government. The new Local Government Act does explain that the authority of the district government is only a little in the forestry sector. Even the District / City Forestry Service has been deleted. Practically the authority of the forestry sector is only in the position of the Provincial and Central Government. The provincial government is considered to be more suitable to resolve forestry conflicts due to its close range. Not infrequently, forestry conflicts occur in areas that are wide enough even across districts. This is the main benchmark for why the Riau provincial government is considered more suitable to be positioned as the main actor in charge of resolving forestry sector conflicts that occur in Pelalawan District. 
Since forestry authority has been reduced, Pelalawan District Government does not have a forestry service like before. The function and role of the forestry service is only at the provincial level. To fill the vacancy in the forestry sector in the field, at the provincial level a $\mathrm{KPH}$ [6] is formed whose position is under the Riau Provincial Environment and Forestry Service. As a tool of government that is directly in contact with forest areas and communities there directly, the KPH position becomes very strategic. Such an FMU position can make $\mathrm{KPH}$ a lower level government institution that can directly hear complaints from various parties, both the community and the provincial government who have this KPH making the Provincial Government worthy of being determined as the main actor working to resolve the conflict. .

The position and role of the central government here is more to make rules and regulations that are the authority. These rules and regulations are, of course, as requested by the Riau Provincial Government as the main actor who resolves the conflict. These rules and regulations must be issued in accordance with what has been understood and attempted by the provincial government in the field

If you stand on the building of social conflict that is included in the affairs of the general government whose authority is with the president, then you can delegate it to the head of government in the area, so social conflict requires budget assistance that must be delegated to the bottom. The delegation of authority was handed over to the head of government in the region / Governor as the head of the Riau provincial government. However, budgeting must also be delegated down. The Riau Governor is also a representative of the central government so that coordination with the Ministry of Environment and Forestry can be easier. If this crosssector coordination is harmonious, then the forestry sector conflict in Pelalawan District can be resolved immediately.

After the resolution of the conflict was handed over to the governor of Riau / Riau Provincial Government, then the first thing to do was to mediate the parties in conflict in this case the community with HTI companies in Pelalawan Regency. With the existing budget, the provincial government can through KPHP or through a special task force team, be able to find a midpoint so that the conflict can be finished soon. The descending team must have good negotiation skills and then also be supported with an adequate operating budget.

Researchers look at some important points that must be included in mediation efforts between the community and the HTI company. The main important point is to return the land of the people who entered the HTI by utilizing the way of exchanging forest areas. This is commonly referred to as enclvae. Enclave is something that must be done by the government if there is community land lost due to entry into the HTI area. The regulatory basis for the exchange of forest areas is in the Minister of Forestry Regulation No: P.32 / Menhhut-II / 2010. Enclave in the regulation means that land owned by individuals or legal entities in the forest area is based on valid evidence in accordance with the provisions of the legislation. Then for technical instructions from exchanging forest areas is in the Regulation of the Director General of Forestry Planning No: P.3 / VII-PSDH / 2014. This method can be done as one of the right solutions. The provincial government can push this to the center for immediate replacement land for the community.

The next way to smooth the path of mediation is by forcing HTI companies to provide Corporate Social Responsibility (CSR) programs to communities around HTI. But the CSR program provided must be a program that benefits the community for the long term. Previously, the provincial government as a mediator was obliged to conduct preliminary research on what CSR programs needed by the community around HTI. Then the Provincial Government submits CSR program recommendations to existing HTI companies. With this, 
the existing CSSR will be more targeted and useful for the life of the community around HTI forever. One example of a program that can be provided is sewing training, handicraft making training, assistance to school facilities and much more.

Then what is not less important is also asking HTI companies to prioritize labor from areas around HTI to be employed in their companies. Thus, the economy of local residents is also helped. This also leads to the depletion of social jealousy between local people and company employees from other regions. For matters of expertise, the company can certainly provide training to the local community before starting work. This makes unemployment decrease in the local communities that are side by side with HTI.

\section{Conclusion}

The government has a mandate from the law to regulate, facilitate, and control the management of conservation areas to face fundamental problems. Both internal problems and pressure from external and dynamic socio-cultural, economic and political conditions around the Industrial Plantation Forest.

Forests cannot be separated from the communities around them, forests are often located in villages or customary territories. Forests that are often used in everyday life, and in the current era of growing forest use, there is often a polemic over the seizure of tenure rights over forests, especially indigenous forests.

The existence of the Company has not been able to make the economy of the community better, on the contrary, the community is no longer free in seeking timber for the survival of the community, so that it often becomes a social conflict between individuals, the community and the government, as well as society with corporations or companies. community The impact of the harmony and harmony of the people is disturbed, in social life every day the people who are pro and contra no longer communicate with each other, even the conflict in the form of physical violence is inevitable both among the community and between the community and the company.

Such conflicts must be resolved immediately. The Riau Provincial Government led by the Governor of Riau is the main actor who is considered appropriate to resolve the existing conflict. Conflict resolution efforts are carried out by maximizing the process of exchanging forest areas, then contributing to the optimization of the company's CSR program and employment of local residents.

Departing from empirical problems, theories and concepts, as well as the results of field research, the suggestions in this study are:

1. The Government must prepare a Government Regulation which contains the position of Governor Provincial Government as the main actor that resolves forestry conflicts

2. The government must participate in making written regulations regarding the obligations of HTI companies to allocate CSR that are on target and also provide employment for residents around HTI

3. The government must supervise the Industrial Park Forest so that it can minimize the conflict.

4. Coordinating with all stakeholders in making every forestry sector policy especially related to the permit for Industrial Plantation Forest Rights (HPHTI)

5. Communities living in Industrial Plantation Forests must get wise treatment from the government and managers of Industrial Plantation Forests, considering that the community is the direct party that receives directly from the adverse impacts of the forest industrialization 


\section{References}

[1] G. Ritzer and D. J. Goodman, Modern Sociological Theory. Jakarta: Prenada Media, 2004.

[2] N. Susan, Sociology of Conflict and Contemporary Conflict Issues. Jakarta: Kencana., 2009.

[3] V. Dugis, Conflict and Conflict Resolution. Surabaya: CSGS, 2011.

[4] Creswell, Qualitative Inquiry \& Research Design, Choosing Among Five Approach, 2nd ed. United State of America: Sage Publication, 2007.

[5] BPKM, "Forestry Research and Development Center Manado 50 years North Sulawesi 1964-2014." : Forestry Research and Development Center Manado Secretariat, Manado, 2014.

[6] Menlhk, "KPH Ministry of Environment and Forestry." .

[7] A. Bandit, "Interview with Atan Bandit at his Personal Residence." .

[8] R. Bindu, "Interview with Rustam Bindu at his Personal Residence." 2017.

[9] Darwis, "Interview with Darwis at his Personal Residence." 2017.

[10] Anonymous, "Interview with Anonymous at his Personal Residence.". 